\title{
MANAGEMENT BY OBJECTIVES W SYSTEMIE MOTYWOWANIA
}

\author{
Kamila Zelga \\ Uniwersytet Jana Kochanowskiego w Kielcach \\ Wydział Prawa, Administracji i Zarządzania
}

\begin{abstract}
Streszczenie: Artykuł przedstawia problematykę motywowania pracowników, które stanowi jeden z najważniejszych elementów zarządzania przedsiębiorstwem. Właściwa motywacja przyczynia się do zwiększenia wydajności oraz jakości wykonywanych zadań, co wpływa na końcowe rezultaty organizacji oraz indywidualne sukcesy pracowników. Celem każdej organizacji jest przyjęcie systemu motywacyjnego dostosowanego do potrzeb kadry pracowniczej oraz determinującego sprawne funkcjonowanie przedsiębiorstwa. W artykule ukazana została istota i pojęcie motywowania pracowników oraz instrumenty pobudzania motywacji, ze szczególnym uwzględnieniem metodyki Management by Objectives oraz związanego z nim systemu feedback. Rezultatem wykorzystania przytoczonej teorii jest ukazanie wyników badań własnych dotyczących motywowania pracowników w wybranym przedsiębiorstwie produkcyjno-handlowym na terenie województwa świętokrzyskiego.
\end{abstract}

Słowa kluczowe: kadra pracownicza, motywowanie, narzędzia motywowania, Management by Objectives

DOI: $10.17512 /$ znpcz.2018.1.13

\section{Wprowadzenie}

Motywacja do pracy stanowi przedmiot zainteresowania uczonych reprezentujących różne dziedziny nauki, m.in. pedagogów, socjologów oraz ekonomistów. Jest to problem wciąż aktualny z uwagi na ciągłe poszukiwanie skutecznej teorii motywacji, której realizacja zapewniałaby kadrom pracowniczym satysfakcję $\mathrm{z}$ wykonanej pracy oraz zadowalające środki płacowe.

W obszarze zarządzania motywacja to istotny element kierowania, determinujący efektywność pracy oraz pobudzanie personelu do zwiększania produktywności, przyczyniającej się do wzmocnienia pozycji firm na dzisiejszym, silnie konkurencyjnym rynku. Pracownicy stanowią najważniejszą część każdej organizacji i to od ich pracy i możliwości, które winny być wsparte odpowiednią motywacją, zależy sukces organizacji.

Celem niniejszego artykułu jest ukazanie systemu motywowania pracowników w przedsiębiorstwie oraz wpływu narzędzi motywowania, w szczególności systemu Management by Objectives, na efektywność ich pracy w świetle literatury przedmiotu oraz badań własnych. Opinie respondenta na temat funkcjonującego systemu motywacyjnego oraz poziomu skuteczności poszczególnych narzędzi motywacyjnych uzyskano metodą wywiadu, przeprowadzonego ze specjalistą działu personalnego badanego przedsiębiorstwa na terenie województwa świętokrzyskiego. 


\section{Istota i znaczenie motywowania pracowników}

Niezmiennie bogata jest wiedza na temat motywacji, zagadnienia przypisanego do psychologii, ale również będącego przedmiotem zainteresowania teorii i praktyki zarządzania, zwłaszcza w kontekście zarządzania zasobami ludzkimi. Świadczy o tym ogromna liczba publikacji naukowych oraz popularnonaukowych z dziedziny motywacji oraz zachowań ludzi w organizacji.

Przez pojęcie motywowania rozumie się proces świadomego i celowego oddziaływania na zachowania ludzi w procesie pracy, poprzez kreowanie warunków umożliwiających im zaspokojenie potrzeb jako efekt ich wkładu w realizację określonych celów organizacji (Pocztowski 2007, s. 207).

R.W. Griffin, doszukując się sensu ogólnego, definiuje motywowanie jako zespół sił, które sprawiają, iż ludzie zachowują się w określony sposób (Griffin 2014, s. 518). Motywowanie polega na wyznaczaniu sobie celu, określeniu kierunku jego realizacji oraz wywołaniu psychologicznych mechanizmów, sprzyjających zachowaniu zgodnemu z przyjętymi założeniami i przebiegiem ich osiągnięcia (Zając 2007, s. 114).

Teoretyczne koncepcje wyjaśniające mechanizm powstawania motywacji do pracy dostarczają informacji niezbędnych do kreowania oraz doskonalenia systemów motywowania ludzi do pracy, które stanowią istotne narzędzie zarządzania wspomagające procesy decyzyjne, planistyczne i kontrolne.

Motywowanie traktowane jest jako jedno z priorytetowych zadań funkcji personalnej w zarządzaniu zasobami ludzkimi każdej organizacji. Zasadniczym jej celem jest oddziaływanie na innych w taki sposób, aby dążyli do wyznaczonego celu. Im silniejsza jest motywacja, tym energiczniejszą aktywność przejawia pracownik i tym większą wykazuje stanowczość w dążeniu do upragnionego rezultatu (Dołhasz i in. 2009, s. 52). Oczywiście warto wziąć pod uwagę realność postawionych celów oraz ocenę szansy ich realizacji w sytuacji swego działania.

$\mathrm{Z}$ uwagi na silnie konkurencyjne otoczenie, w jakim przyszło funkcjonować obecnym przedsiębiorstwom, ranga motywowania pracowników nabiera coraz większego znaczenia. Mają na to wpływ transformacje społeczne oraz gospodarcze, jakie pojawiają się zarówno na polskim rynku, jak i na arenie gospodarki światowej. Motywowanie niewątpliwie należy do najtrudniejszych funkcji zarządzania wpływających na produktywność oraz innowacyjność zatrudnionej kadry, które to przesądzają o konkurencyjności firmy oraz jej dominacji na rynku (Lewicka 2010, s. 24). Niełatwo jest bowiem znaleźć takie bodźce, które wpłyną mobilizująco na zachowanie pracowników oraz przyczynią się do wzrostu rentowności przedsiębiorstwa.

Zainteresowanie problematyką motywowania personelu wynika również z przeświadczenia, że trwałe i silne usytuowanie oraz atrakcyjność na rynku przedsiębiorstwo zyskuje dzięki pozyskaniu właściwego kapitału ludzkiego. Stanowi ono niezwykle cenne bogactwo przedsiębiorstwa, którego aktywność determinuje działalność organizacji oraz dalszy jej rozwój. Umotywowany personel jest gwarancją udanej i owocnej pracy oraz postępującego kroku organizacji w kierunku realizacji jej strategii i pozycji na rynku (Terzi 2016, s. 126). 


\section{Instrumenty pobudzania motywacji}

Narzędzia motywowania stanowią istotny zbiór metod, reguł, sposobów i form postępowania oraz rozwiązań organizacyjnych, które regulują proces motywacyjny w przedsiębiorstwie (Pietroń-Pyszczek 2015, s. 29). Oddziałują bezpośrednio na zachowania ludzi, wpływając na ich świadomość, stosunek do pracy i przełożonych, a także kształtując wzajemne relacje (Pietroń-Pyszczek 2015, s. 33). W kontekście podejmowania przez pracowników uznaniowych zadań, zwiększania swoich kompetencji oraz jakości pracy instrumenty motywowania stanowią podstawę do przełamywania skłonności biernej i asekuracyjnej postawy.

Sztuka efektywnego motywowania ugruntowana jest na umiejętnym doborze narzędzi motywacyjnych, dostosowanych do warunków i potrzeb organizacji oraz indywidualnych jednostek.

Szczególne znaczenie wśród kształtowania się materialnych narzędzi motywowania niezmiennie stanowią wynagrodzenia. Zwyczajowo określane są jako wszelkie wypłaty należne pracownikowi za pracę wykonywaną w ramach stosunku pracy (Pietroń-Pyszczek 2015, s. 73). Kodeks pracy definiuje wynagrodzenia za pracę jako „wypłaty pieniężne oraz wartość świadczeń w naturze bądź ich ekwiwalenty należne pracownikowi z tytułu pracy" (Ustawa z dnia 26 czerwca 1974 r. ..., art. $890 \S 2)$.

Każda jednostka, organizacja, niezależnie od wielkości, charakteru czy formy gospodarowania, tworzy system wynagrodzeń, czyli zbiór zasad, przepisów i norm regulujących ustalanie wynagrodzeń oraz sposób ich korygowania (Warwas, Rogozińska-Pawełczyk 2016, s. 58). Warto więc wymienić fundamentalne składniki wynagrodzeń (Pietroń-Pyszczek 2015, s. 75):

- wymagania pracy oraz jej efektów (praca zasadnicza, premia, dodatek funkcyjny);

- czas pracy (dodatek za pracę w godzinach nadliczbowych i dodatek za pracę w porze nocnej);

- warunki pracy (dodatek za pracę w warunkach szkodliwych i niebezpiecznych dla zdrowia i życia);

- staż pracy (dodatek stażowy i premia jubileuszowa).

Dobierając te elementy, należy starać się, aby system wynagrodzeń organizacji charakteryzował się schematyczną wewnętrzną strukturą pracy, natomiast pracownik pozostawał świadomy liczby funkcjonujących składników wynagrodzeń.

Warto nadmienić, że wiele dzisiejszych przedsiębiorstw rutynowo ugruntowuje swój system wynagrodzeń na konsolidacji wynagrodzenia stałego wraz z jego częścią zmienną, koncentrując się na docenieniu pracowników kompetentnych oraz wykazujących się oczekiwanymi wynikami pracy.

Najczęściej stosowane formy wynagrodzeń zmiennych stanowią (Meysztowicz, Policewicz, Antonowicz 2016, s. 14):

1. premia regulaminowa - przyzwana na podstawie wyraźnie zapisanych w regulaminie kryteriów i zasad jej przyznawania;

2. premia uznaniowa - przysługująca pracownikom, którzy wzorowo wypełniają powierzone obowiązki oraz wykazują inicjatywę w pracy, podnosząc jej wydaj- 
ność, jakość oraz nieprzeciętnie przyczyniają się do wykonywania zadań na rzecz zakładu pracy (http://kadry.infor.pl/...);

3. prowizja - wyliczana bezpośrednio od wartości sprzedaży, przeważnie jako procent od zrealizowanej marży lub płaska stawka za zbyty produkt;

4. profit sparing - oparty na udziałach w zyskach, którego specyfika polega na wypłacaniu pracownikowi rocznej jednorazowej wypłaty w określonej procentowo wysokości, liczonej od osiągniętego przez przedsiębiorstwo zysku.

Charakter wdrażanych rozwiązań wynika bezpośrednio z realizowanej przez przedsiębiorstwo strategii oraz służy utrzymaniu wysokiego poziomu zaangażowania pracowników w proces tworzenia przewagi konkurencyjnej (Woźniak 2012, s. 112).

\section{Metoda zarządzania przez cele}

Teoretyczne ugruntowanie kierowania motywacją pracowników przy użyciu wynagrodzenia zmiennego wiąże się z propozycją zarządzania przez cele (Management by Objectives), spopularyzowaną $\mathrm{w}$ latach 50. przez Petera Druckera (Woźniak 2012, s. 112). Strategia ta stała się skutecznym elementem kultury biznesowej, rutynowo wdrażającej się w strukturę zarządzania, jednocześnie stanowiąc renomę wśród większości obecnych korporacji międzynarodowych.

Kluczem do zrozumienia koncepcji zarządzania przez cele jest samo pojęcie celu, charakteryzowane jako pobudka do wszelakich dążeń, które ściśle utożsamiane jest ze zmianą oraz komponowaniem innowacyjnej wartości dla firmy. Skonkretyzowane cele powinny odznaczać się określonym stanem docelowym, tzw. klarowną wizją końca, co wiąże się z szeregiem zmian koncepcji, procedur oraz sposobów działania (http://sharky.pl/...).

Precyzując dążenia, kadra zarządzająca odpowiada na pytania (Reinfuss 2011, s. 36-37):

- Co należy zmienić?

- Co nowego wprowadzić?

- Jak usprawnić obecny proces zarządzania, aby osiągać założone wskaźniki ekonomiczne?

- Jak zdobyć je taniej i zagwarantować ich poprawę w przyszłości?

Zmiana trwałej wartości firmy, którą tworzy menedżer ponad bieżący i określony w budżecie plan biznesowy, jest przedmiotem MBO, stanowiąc w konsekwencji podstawę do jej premiowania (Reinfuss 2011, s. 36-37). Menedżer w swojej pracy odpowiedzialny jest nie tylko za skuteczne kierowanie powierzoną sferą zarządzania, uzyskując w rezultacie wynagrodzenie zasadnicze, ale również za obszar modernizacji oraz wprowadzanie innowacyjnych rozwiązań podnoszących nieprzerwanie wartości firmy, traktowane jako postawione sobie cele.

Narastająca atrakcyjność tej techniki wynika z założenia, że organizacja dąży do połączenia rezultatów indywidualnych pracowników we wspólny wysiłek zapewniający sukces całej organizacji. Każdy z podwładnych powinien wnieść określony wkład w efektywność swojej jednostki organizacyjnej, co wpływa na końcowe rezultaty organizacji. 
W Polsce idea uczestnictwa w zarządzaniu ma jedynie dwudziestoletnią praktykę. Jednakże polscy przedsiębiorcy błyskawicznie wyrównują ubytki w stosunku do gospodarek rozwiniętych, w kontekście wprowadzania nowinek w zarządzaniu, niezbędnych dla realizacji etapów rozwoju organizacji. MBO pełni istotną rolę w tym procesie, ponieważ (Reinfuss 2011, s. 36-37):

- Egzekwuje skrupulatność w stawianiu celów i zadań oraz mobilizuje do ich kontrolowania i kierowania wynikami.

- Daje neutralne podłoże do oceny kadry kierowniczej i mierzalną podstawę systemów premiowych.

- Pozytywnie wpływa na motywację pracowników do podejmowania coraz to ambitniejszych zadań.

- Stanowi skuteczną technikę osiągania ponadprzeciętnych wyników, pozwalających osiągnąć zwrot z inwestycji oraz efekty przewyższające plany biznesowe.

MBO to metoda o olbrzymiej sile przebicia oraz niezwykłej skuteczności, która modyfikuje funkcjonowanie całej organizacji. Menedżerowie stają się bardziej odpowiedzialni za biznes, podejmując coraz to nowe decyzje, determinujące świadomość potrzeb rozwojowych podwładnych oraz własnych (http://sharky.p1/...). W konsekwencji możliwe staje się uzyskanie mobilizacji do realizacji kolejnych, coraz to bardziej wymagających celów.

\section{Feedback nakierowany na przyszlość}

Sukces każdej organizacji w znacznym stopniu uzależniony jest od właściwie ukierunkowanej rozmowy pracodawcy z podwładnym, dotyczącej realizacji indywidualnych celów, które mają wpływ na wynik ekonomiczny przedsiębiorstwa. Rozmowa, podczas której pracownik dowiaduje się o wynikach swojej pracy, nazywana jest feedbackiem. Konwersacja ta jest niezwykle istotna dla młodego pokolenia, wchodzącego na rynek pracy, które operatywnie szuka informacji zwrotnej u swoich przełożonych, oczekując systematycznych rozmów, możliwości weryfikacji wyników czy też wskazówek rozwojowych (Berłowski 2014, s. 16).

W ramach feedbacku pracownikom powinien zostać przedstawiony właściwy kierunek wykonywania ich pracy, czas jej realizacji czy potencjalne wsparcie w jej dążeniu. Dotychczas dominujące podejście weryfikowało poziom realizacji zadań pracownika na koniec okresu rozliczeniowego, co odbierane jest raczej jako wartościowanie pracownika przez przełożonego, będące źródłem stresu oraz braku entuzjazmu (Berłowski 2014, s. 16).

Zasadnicza różnica w sposobie postrzegania ocen oraz metody feedback polega na tym, iż z punktu widzenia specjalistów ds. HR, czyli działu odpowiadającego za sprawy pracownicze, ocena ta stanowi tylko potwierdzenie stanu przeszłego, np. zrealizowania zadania, z kolei dla menedżera ważniejszy jest stan aktualny, możliwy do modyfikacji (Berłowski 2014, s. 18). Dlatego też rozmowa oceniająca powinna dążyć do poprawy efektywności, a nie tylko skupiać się na ocenie umiejętności i uzdolnień pracowników.

Feedback to skuteczna forma komunikacji, dostarczająca aktualnego spojrzenia z zewnątrz oraz uwidaczniająca obszary istotne do zmiany, co wpływa na większą 
świadomość popełnianych błędów przez pracowników, zintensyfikowanie ich kompetencji, wzmacnianie pożądanych zachowań oraz poszerzanie perspektyw (Berłowski 2014, s. 18). Prawidłowo udzielany feedback sprawi, że pracownicy dowiedzą się, co jest ich mocnym punktem, a nad jakimi kompetencjami muszą jeszcze popracować. Przełożeni natomiast, stosując go regularnie, będą mogli lepiej zarządzać zespołem i motywować jego członków, a z pomocą nowych technologii z łatwością sprawdzą jego efekty.

Przewiduje się, iż nawyk przekazywania informacji zwrotnej będzie coraz częściej zauważalny w całej organizacji, również po stronie pracownika, od którego finalnie zależy zmiana jego zachowania oraz końcowe rezultaty organizacji (Berłowski 2014, s. 19).

\section{Cel, przedmiot oraz metodologia badań własnych}

Cel pracy zrealizowany został poprzez badanie empiryczne prowadzone techniką kwestionariuszową za pośrednictwem wywiadu. W ramach wybranej metodyki wykorzystano metodę wywiadu swobodnego przeprowadzonego ze specjalistą ds. HR, w oparciu o stworzone dyspozycje do wywiadu.

Respondent obecnie zajmuje stanowisko zastępcy dyrektora personalnego, natomiast $\mathrm{w}$ badanej organizacji zatrudniony jest od 5 lat. Wywiad przeprowadzony został na początku stycznia 2018 roku w siedzibie przedsiębiorstwa. Część zasadnicza kwestionariusza składała się z 10 pytań. W większości były to pytania otwarte zadawane w rozmowie bezpośredniej, prowadzonej zgodnie z założonym celem i według wcześniej opracowanego planu.

Rozmowa została zarejestrowana za pomocą dyktafonu, następnie po jej odsłuchaniu sformułowano odpowiednie wnioski oraz spostrzeżenia. Wyboru przedsiębiorstwa dokonano w sposób celowy, z jednej strony kierując się wielkością firmy i złożonością systemu motywacyjnego, z drugiej zaś strony -zapotrzebowaniem kierownictwa na przeprowadzenie analizy i dostępnością materiałów.

Analizowane przedsiębiorstwo jest czołowym producentem i liderem segmentu na rynku w branży materiałów budowlanych. Firma stanowi grupę spółek produkcyjnych oraz handlowych rozproszonych lokalizacyjnie w Europie. Procesy produkcyjne realizowane są obecnie na terenie trzech fabryk, natomiast przedsiębiorstwo kompleksowo działa w 61 państwach.

Bogaty wachlarz asortymentów produkcyjnych oferowanych przez analizowane przedsiębiorstwo świadczy o wytwarzaniu produktów wysokiej jakości oraz funkcjonalnych i niebywale wytrzymałych, a przy tym designerskich i gustownych. Jednakże najlepszą rekomendację ich pracy stanowią w pełni usatysfakcjonowani klienci oraz sukcesywnie wzrastające przychody ze sprzedaży. 


\section{Motywowanie pracowników na przykladzie przedsiębiorstwa w województwie świętokrzyskim}

Część empiryczną, właściwą dla celu pracy oraz stanowiącą jednocześnie hipotezę roboczą, rozpoczęto od analizy przedmiotu wagi motywacji pracowników w funkcjonowaniu przedsiębiorstwa. Respondent za podstawę swoich rozważań przyjął stwierdzenie, iż motywacja pracowników odgrywa kluczową rolę w działalności analizowanej firmy. Za uzasadnienie tezy przyjął, iż zasoby oraz procesy każdej organizacji wykorzystywane są do osiągnięcia zysku, natomiast to, jak zostaną one zużytkowane oraz $\mathrm{w}$ jakim obszarze $\mathrm{w}$ tym czasie znajdzie się firma, jest wynikiem zagospodarowania nadmienionych zapasów przez kapitał ludzki.

Opiniodawca bezapelacyjnie skonstatował, że pracownicy tworzą istotny zasób każdej organizacji. Ludzie motywowani do bardziej wydajnej pracy oraz mobilizowani do generowania z siebie jak najwięcej odznaczają się zdecydowanie większym zaangażowaniem w wykonywanie powierzonych obowiązków, a w efekcie potęguje to prawdopodobieństwo osiągnięcia korzystnego wyniku finansowego przez firmę.

Bezpośrednim aspektem związanym z motywacją pracowników jest wpływ poziomu otrzymywanego wynagrodzenia na jakość pracy i ogólne zaangażowanie kadry pracowniczej. Respondent wyjaśnił, że w strukturze firmy znajdują się określone poziomy stanowisk, bardzo mocno powiązane ze stażem pracy. Poziom wynagrodzenia na stanowiskach szeregowych czy młodszych specjalistów jest relatywnie niski w porównaniu z innymi, chociażby menedżerskimi pozycjami, dlatego też efekt wzrostu wynagrodzenia bardzo mocno odczuwalny jest przy jego niższym poziomie. $Z$ tego względu na pewno nie można lekceważyć wynagrodzenia zasadniczego jako motywatora, natomiast $\mathrm{w}$ firmie został stworzony również bardzo sprawnie funkcjonujący system motywacji płacowej, czyli system premiowy.

Podłoże do stworzenia właściwego systemu premiowego stanowiła analiza dotychczasowej kompozycji, weryfikacja poziomu jego efektywności oraz zebranie proponowanych rozwiązań do wdrożenia w tym obszarze.

Zgodnie z nową strukturą wprowadzono jednolity procent premii od stawki zasadniczej dla wszystkich pracowników: do $10 \%$, do $20 \%$ lub do $30 \%$.

$\mathrm{W}$ analizowanym przedsiębiorstwie dominuje ujednolicona struktura wynagrodzeń, co wiąże się z przydzieleniem określonego procentu premii z daną częstotliwością dla konkretnych grup pracowniczych.

$\mathrm{Z}$ punktu widzenia technicznych zasad realizacja tego systemu przedstawia się następująco:

- „blue collars”, czyli pracownicy bezpośredniej produkcji - mogą osiągnąć do $10 \%$ premii miesięcznych;

- „white collars”, czyli personel na stanowiskach specjalistycznych związanych $\mathrm{z}$ zarządzaniem produkcją, sprzedażą oraz administrowaniem - może uzyskać do $20 \%$ premii w ujęciu kwartalnym;

- menedżerowie działu - mogą uzyskać do $30 \%$ premii od wynagrodzenia zasadniczego, ustalanej kwartalnie;

- dyrektor pionu - mogą uzyskać do 30\% premii w ujęciu rocznym. 
Nietrudno zauważyć, że na stanowiskach wymagających powtarzalności działań, na których niemożliwe jest wyznaczanie ambitnych zadań, obowiązuje $10 \%$ udziału premii w stosunku do wynagrodzenia zasadniczego, natomiast w obszarach pracy projektowej lub w przypadku handlowców udział ten znacznie wzrasta, nawet do $30 \%$.

Jedną ze sposobności urzeczywistnienia struktur premiowych jest system zarządzania przez cele krótkoterminowe organizacji, czyli tzw. Management by Objectives (MBO). Przełożony w ramach specyfiki wdrożenia MBO wyznacza pracownikowi indywidualne cele na dany kwartał lub rok, które przyjmują postać opisową bądź projektową.

Głównym powodem, dla którego firmy coraz częściej są zainteresowane wdrażaniem systemu MBO, jest ukierunkowanie wysiłków pracowników na priorytetach określanych przez przełożonych i wynagradzanie ich $\mathrm{w}$ oparciu o realizacje zdefiniowanych przez menedżerów oraz zaakceptowanych przez kadrę pracowniczą celów (http://www.figpolska.pl/...).

Warto nadmienić, że podsumowanie realizacji celów MBO z uwzględnieniem wszelkich ważnych aspektów powinno odbyć się podczas rozmowy przełożonego zpracownikiem, zwanej udzieleniem feedbacku, czyli informacji zwrotnej.

Częstotliwość udzielenia feedbacku jest ściśle uzależniona od umiejętności managementu, obszarów pracy, stanowisk i zakresu obowiązków pracowniczych. Najczęściej momentem dialogu między przełożonym a podwładnym jest ostatni tydzień danego kwartału.

Właściwie przekazany feedback pozwala pracownikom zasięgnąć opinii na temat oceny ich pracy przez przełożonego, poprawności wykonywania zadań oraz obszarów, w których ich realizacja powinna być wydajniejsza.

$\mathrm{W}$ ostatnich latach, kiedy na rynku pracy dominuje młodsza generacja, kadra pracownicza zdecydowanie częściej oczekuje feedbacku od pokolenia pracowniczego wcześniejszych generacji, które to zwyczajnie inaczej podchodziło do swojej pracy.

Jednakże bez względu na to, w jakim wieku i generacji znajdują się pracownicy, obowiązkowo przynajmniej raz w kwartale taka informacja zwrotna powinna zostać udzielona, gdyż pozwala ona zatrudnionym uzyskać poczucie zaufania, satysfakcji, ale też przywiązania do firmy i większego zaangażowania w swoje obowiązki, co przekłada się na późniejsze wyniki firmy.

Bardzo ważne narzędzie motywacyjne według respondenta nieprzerwanie stanowią szkolenia. Przedsiębiorstwo korzysta z kursów przygotowanych przez parterów biznesowych, które są dostosowane do potrzeb firmy oraz samych pracowników.

Z perspektywy osoby odpowiedzialnej za organizowanie programów szkoleniowych zwraca się uwagę na merytorykę szkolenia, element badania potrzeb szkoleniowych oraz sylwetkę trenera jako osoby odpowiedzialnej za jakość realizacji zajęć. Dział personalny inicjuje szkolenia w każdym roku, z naciskiem na obszary sprzedaży i produkcji.

Z kolei z punktu widzenia finansowych nad pozafinansowymi narzędziami motywacyjnymi, respondent uważa, iż finanse bez wątpienia stanowią ważny poziom 
higieny każdego pracownika, który musi zaspokoić ze względu na ciążące na nim zobowiązania.

Biorąc pod uwagę uwarunkowania obecnego rynku pracy, coraz częściej można dostrzec ujawniające się braki wśród dobrze wynagradzanych pracowników. Najczęściej są to wyznawane wartości oraz priorytety, które pracownik chciałby realizować w miejscu pracy, natomiast w sytuacji, gdy firma nie wychodzi naprzeciw jego oczekiwaniom, może on rozważać opcje zmiany pracy.

Czynnikami, które zdaniem respondenta zdecydowanie występują w badanym przedsiębiorstwie, są premie, udzielane w oparciu o wyniki pracy.

Dodatkowo opiniodawca wymienił awans, najczęściej na poziomie wewnętrznym, jakość narzędzi pracy, które w jego opinii usytuowane są na bardzo wysokim, a wręcz przesadnym poziomie, oraz zniżki na usługi firmy bogatego wachlarza asortymentu, jakim dysponuje badana organizacja.

Zdaniem badanego w przedsiębiorstwie najrzadziej występują nagrody pieniężne oraz karnety wstępu do obiektów sportowych, natomiast równoznaczny z elastycznym czasem pracy jest obowiązujący system wyjść prywatnych, związany $\mathrm{z}$ osobistymi sprawami, które pracownik musi zrealizować $\mathrm{w}$ czasie pracy, ustalając to wcześniej z przełożonym.

$\mathrm{W}$ opinii respondenta motywowanie nie stanowi jedynie istotnego aspektu wśród pracowników. Motywacja menedżerów, zarządu i top managementu jest równie ważna, ale nieco inaczej postrzegana. Od takich osób wymaga się o wiele silniejszego udziału motywacji wewnętrznej, która napędza kolejne działania pracowników reprezentujących dany obszar przedsiębiorstwa.

\section{Podsumowanie}

Motywowanie pracowników to podstawowa działalność każdej organizacji. Jednostka organizacyjna w pełni uświadomiona, jak cennym zasobem są pracownicy, stoi na drodze do sukcesu.

W dobie konkurencyjnego rynku pracy, na którym przyszło funkcjonować dzisiejszym przedsiębiorstwom, motywacja pracownicza nie należy do trywialnych wyzwań menedżerskich. Pracownicy oczekują coraz to bardziej innowacyjnych narzędzi motywacyjnych, które w pełni zaspokoją ich potrzeby.

W świetle badań własnych wykazano, że:

1. W przedsiębiorstwie funkcjonuje efektywny system motywowania pracowników, wpływający na jakość i zaangażowanie pracowników. Płaca zasadnicza stanowi stały element wynagrodzeń, wynikający z Kodeksu pracy oraz dostosowany do konkretnych stanowisk pracowniczych. Istotnym aspektem motywacyjnym $\mathrm{w}$ analizowanym przedsiębiorstwie jest dynamicznie rozwijający się system premiowy, którego wielkość i częstotliwość przyznawanych gratyfikacji uzależniona jest od poziomu zajmowanego miejsca w strukturze zatrudnienia oraz jej obszaru działalności.

2. System premiowy spełnia swoją motywacyjną funkcję w przedsiębiorstwie.

Wyniki badań wskazują, że w analizowanej firmie dominuje ujednolicona struktura wynagrodzeń, co wiąże się z przydzieleniem określonego procentu premii 
$\mathrm{z}$ daną systematycznością dla konkretnych grup pracowniczych. Realizowane przez pracowników cele zdywersyfikowane są metodą Management by Objectives, stanowiąc jednocześnie zalążek do udzielania obopólnego feedbacku.

Respondent uznał, iż motywacja pracowników odgrywa kluczową rolę w funkcjonowaniu analizowanej firmy, której zasoby oraz procesy wykorzystywane są do wypracowania zysku przedsiębiorstwa. Kwestia ich zużytkowania w konkretnych obszarach działania determinuje zagospodarowanie tychże zapasów przez kadrę pracowniczą.

\section{Literatura}

1. Berłowski P. (2014), Czy feedback spetnia swoją funkcję?, „Personel i Zarządzanie”, nr 4, s. 12-22.

2. Dołhasz M., Fudaliński J., Kosala M., Smutek H. (2009), Podstawy zarządzania. Koncepcje - strategie - zastosowania, Wydawnictwo Naukowe PWN, Warszawa.

3. Dołożyńska K. (2015), Motywowanie pozafinansowe, „Personel i Zarządzanie”, nr 3, s. 48-52.

4. Griffin R.W. (2014), Podstawy zarządzania organizacjami, Wydawnictwo Naukowe PWN, Warszawa.

5. http://kadry.infor.pl/poprzednie_tematy_dnia/401608,2,Premia-regulaminowa-a-premiauznaniowa.html (dostęp: 29.11.2017).

6. http://sharky.pl/?m=sit.wiedza\&did=18\&dtit=mbo_zarzadzanie_przez_cele (dostęp: 29.11.2017).

7. http://www.figpolska.pl/mbo-sposob-na-racjonalne-zarzadzanie-kosztami-wynagrodzen (dostęp: 30.11.2017).

8. Lewicka D. (2010), Zarządzanie kapitałem ludzkim w polskich przedsiębiorstwach, Wydawnictwo Naukowe PWN, Warszawa.

9. Meysztowicz K., Policewicz K., Antonowicz M. (2016), Premie uznaniowe: jak uelastycznić system wynagrodzeń $i$ nie stracić zaangażowania pracowników, „Personel i Zarządzanie", nr 2, s. 46-49.

10. Pietroń-Pyszczek A. (2015), Motywowanie pracowników. Wskazówki dla menedżerów, Wydawnictwo Marina, Wrocław.

11. Pocztowski A. (2007), Zarzadzanie zasobami ludzkimi, PWE, Warszawa.

12. Reinfuss R. (2011), MBO na talerzu. Zarządzanie przez cele $w$ organizacji, „Personel i Zarządzanie", nr 9, s. 36-40.

13. Terzi E. (2016), Wpływ motywowania pracowników na jakość i efektywność pracy w przedsiębiorstwie, [w:] Walczak M. (red.), Wybrane problemy wspótczesnej ekonomii, Uniwersytet Jana Kochanowskiego w Kielcach, Kielce, s. 125-138.

14. Ustawa z dnia 26 czerwca 1974 r. Kodeks pracy (Dz.U. 1974 nr 24 poz.141, z późn. zm.).

15. Warwas I., Rogozińska-Pawełczyk A. (2016), Zarządzanie zasobami ludzkimi w nowoczesnej organizacji. Aspekty organizacyjne $i$ psychologiczne, Akademia Zarządzania i Finansów, Łódź.

16. Woźniak J. (2012), Współczesne systemy motywacyjne. Teoria i praktyka, Wydawnictwo Naukowe PWN, Warszawa.

17. Zając C. (2007), Zarządzanie zasobami ludzkimi, Wydawnictwo Wyższej Szkoły Bankowej, Poznań. 
MOTIVATION AS A COMPANY MANAGEMENT PROCESS - A CASE STUDY

Abstract: The article discusses issues related to motivating employees, which is one of the most important elements of business management. Proper motivation contributes to the increase of productivity and quality of performed tasks, which affects the final results of the organization and the success of individual employees. The goal of every organization is to adopt an incentive system tailored to the needs of employees and facilitating the smooth functioning of the company. The article presents the concept of motivating employees and the instruments used to stimulate motivation, with particular emphasis on the methodology of Management by Objectives and the related feedback system. The result of the quoted theory is the presentation of the results of author's research on motivating employees in a selected production and trading company in the province of Świętokrzyskie.

Keywords: workforce, motivating, motivating tools, Management by Objectives 